\title{
Alaska Standard Time
}

National Cancer Institute

\section{Source}

National Cancer Institute. Alaska Standard Time. NCI Thesaurus. Code C116268.

Local standard time, based at the 135th meridian west of the Greenwich Observatory, established as nine hours behind Coordinated Universal T ime. 